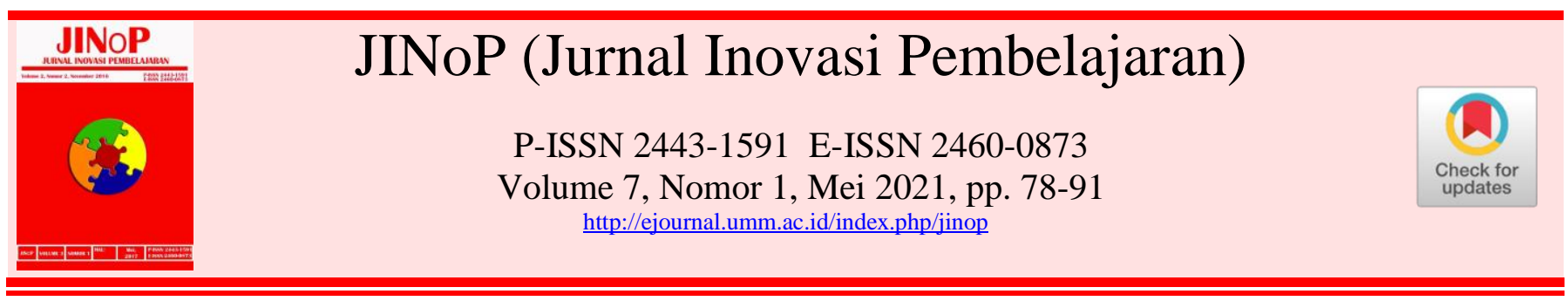

\title{
Peningkatan kualitas pembelajaran melalui lesson study learning community pada materi "waktu 24 jam" di Sekolah Dasar
}

\author{
Sri Wahyuni ${ }^{1)}$, Roro Eko Susetyarini ${ }^{2) *}$, Wahyu Prihanta ${ }^{3)}$, Firdiani Yuliana ${ }^{4)}$ \\ ${ }^{1}$ Program Studi Pendidikan biologi, Fakultas Keguruan dan Ilmu Pendidikan, Universitas \\ Muhammadiyah Malang, Jl. Raya Tlogomas 246, Malang, Indonesia \\ ${ }^{2}$ Program Studi Pendidikan biologi, Fakultas Keguruan dan Ilmu Pendidikan, Universitas \\ Muhammadiyah Malang, Jl. Raya Tlogomas 246, Malang, Indonesia \\ ${ }^{3}$ Program Studi Pendidikan biologi, Fakultas Keguruan dan Ilmu Pendidikan, Universitas \\ Muhammadiyah Malang, Jl. Raya Tlogomas 246, Malang, Indonesia \\ ${ }^{4}$ SD Negeri Junrejo 1 Batu, Jl. Hasanudin No.51, Batu, Jawa Timur, Indonesia
}

swahyuni48@gmail.com, susetyorini@umm.ac.id*,wahyuprihanta@gmail.com,

firdianiyuliana@gmail.com

*Penulis Koresponden

\begin{tabular}{|c|}
\hline ABSTRAK \\
\hline $\begin{array}{l}\text { Tugas utama guru dalam proses pembelajaran adalah mengantarkan peserta untuk mencapai } \\
\text { tujuan belajarnya. Dengan demikian guru dituntut untuk selalu meningkatkan kualitas } \\
\text { pembelajarannya, salah satunya melalui Lesson Study Learning Community (LS-LC). Tujuan } \\
\text { penelitian ini adalah mendeskripsikan pelaksanaan LS-LC di SD Junrejo I Batu, pada materi } \\
\text { "waktu } 24 \text { jam". Penelitian kualitatif ini menggunakan studi kasus tunggal dan pemaparan data } \\
\text { secara naturalistik. Obyek penelitian adalah guru dan siswa kelas II sejumlah } 28 \text { orang. Ada } 3 \\
\text { tahapan pada pelaksanaan } L S \text { - LC, yaitu plan, do dan see. Teknik pengumpulan data melalui } \\
\text { dokumentasi dan wawancara tidak terstruktur. Data dianalisis secara deskripsi kualitatif dan } \\
\text { kuantitatif. Temuan penelitian dipaparkan secara naratif, meliputi kegiatan guru dan siswa } \\
\text { selama proses LS-LC. Guru berkolaborasi dan berkreasi merancang pembelajaran; siswa } \\
\text { mengamati langit, berdiskusi, membandingkan jam digital dan nondigital serta mempresentasikan } \\
\text { hasil diskusi kelompoknya. Observer mengamati "bagaimana siswa belajar". Guru, observer dan } \\
\text { dosen merefleksi kegiatan pembelajaran yang telah berlangsung. Pelaksanaan LS-LC di kelas II } \\
\text { SD Junrejo I Batu, pada materi "waktu } 24 \text { jam" telah berjalan dengan baik. Siswa mampu } \\
\text { memahami materi sebanyak } 60 \% \text {, mampu berkolaborasi dalam kelompok } 45 \% \text {, mengungkapkan } \\
\text { senang, gembira, semangat dan ceria sebanyak } 90 \% \text {. Terdapat peningkatan kemampuan } \\
\text { pemahaman kolaborasi dan komunikasi pada siswa. Perlu replanning pengaturan tempat duduk } \\
\text { dan anggota kelompok. } \\
\text { Kata Kunci: Lesson Study Learning Community; Waktu } 24 \text { Jam; Sekolah Dasar }\end{array}$ \\
\hline ABSTRACT \\
\hline $\begin{array}{l}\text { The main task of the teacher in the learning process is to lead participants to achieve their learning } \\
\text { goals. Thus, teachers are required to always improve the quality of their learning, one of which is } \\
\text { through the Lesson Study Learning Community (LS-LC). The purpose of this research is to } \\
\text { describe the implementation of the Lesson Study Learning Community in SD (Sekolah Dasar- } \\
\text { Primary School) Junrejo I, in "the } 24 \text {-hour clock" material. This qualitative research employed a } \\
\text { single case study and explained it naturally. The respondents were one teacher and } 28 \text {-second } \\
\text { graders. There were three stages in the implementation of lesson study, namely: plan, do and see. } \\
\text { The data collection technique were using documentation and unstructured interview. The data } \\
\text { were analyzed in a quantitative and qualitative description. The findings in the planned activity } \\
\text { were the collaboration of teachers and lecturers in innovating and creating chapter and lesson } \\
\text { design of "the 24-hour clock" material, considering the characteristic of students. In the open } \\
\text { class (do the activity), the students were conducting discussions and observations. During }\end{array}$ \\
\hline
\end{tabular}


learning, the students were comparing digital and non-digital clocks while lecturers and teachers were observing the learning process. In the seen activity, the observation result from teachers and lecturers were revealed. The implementation of Lesson Study Learning Community in grade II SD Junrejo I, on the material "24 hour time" had been going well. But the results shown that students were able to understand the material as much as $60 \%$, students were able to collaborate in groups $45 \%$, student's expression was happy, excited, motivating, and cheerful, as much as $90 \%$. It needs replanning with changes in seating arrangements, group arrangements, and group members.

Keywords: Lesson Study Learning Community; Time; Primary School

diunggah: 2019-11-30, direvisi: 2021-03-30, diterima: 2021-04-22, dipublikasi: 2021-05-24

Copyright (c) 2020 Wahyuni et al

This is an open access article under the CC-BY license

Cara sitasi: Wahyuni, S., Eko Susetyarini, R., Prihanta, W., \& Yuliana, F. (2021). Peningkatan kualitas pembelajaran melalui lesson study learning community pada materi "waktu 24 jam" di Sekolah Dasar. JINoP (Jurnal Inovasi Pembelajaran), 7(1), 78-91. https://doi.org/10.22219/jinop.v7i1.10477

\section{PENDAHULUAN}

Pembelajaran merupakan proses interaksi antara pendidik, peserta didik, serta media pembelajaran. Melalui proses interaksi tersebut, peserta didik dapat mengembangkan pola pikir secara keterampilan secara aktif. Pembelajaran yang berlangsung secara interaktif, menyenangkan, inspiratif, menantang akan memotivasi siswa untuk mencapai tujuan dan kompetensi yang diharapkan (Anwar, 2017; Sumiyati, 2017). Pembelajaran interaktif yang menyenangkan, menantang dan inovatif sebagaimana yang dicanangkan Pemerintah melalui Peraturan Presiden Republik Indonesia nomor 32 tahun (2013) merupakan pembelajaran yang dipersiapkan dalam menghadapi Revolusi Industri 4.0. yang mengarah ke sekolah modern abad 21. Sekolah model abad 21 dibentuk berdasarkan prinsip dasar pencapaian secara simultan antara kualitas/quality dan kesetaraan/equality (Sato, 2014b).

Salah satu faktor kunci tingginya kualitas pembelajaran adalah adanya peningkatan profesionalitas pendidik sebagai tenaga pendidik (Christ et al., 2017; Kurniawan, 2016) Peningkatan profesionalitas guru dalam pembelajaran dapat diidentifikasi dari kemampuan merancang pembelajaran dengan metode yang sesuai dengan kebutuhan kurikulum dan perkembangan zaman (Alshwaikh \& Adler, 2017; Asanuma, 2012; Rock \& Wilson, 2005) Pada abad 21 memerlukan reformasi sekolah terkait proses pembelajaran, berupa visi dan filosofi, yaitu komunitas belajar (Learning community). Sedangkan misi komunitas belajar di sekolah adalah menjamin hak belajar siswa dan meningkatkan kualitas pembelajaran (Sato, 2014b). Hal ini merupakan tantangan besar bagi sekolah karena harus ada kesepakatan antar para pihak, yaitu antara sekolah, komite sekolah, kepala sekolah, guru, maupun dinas pendidikan. Filosofi komunitas belajar ada 3 kegiatan, yaitu pembentukan komunitas belajar professional, pembelajaran kolaboratif di kelas dan kolegialitas para guru, serta partisipasi dari para orang tua dan masyarakat (Coenders, F, \& Verhoef, 2018; Wahyuningtyas N, Ratnawati N, 2015)

Salah satu cara meningkatkan kualitas pembelajaran adalah melalui kegiatan lesson study. Melalui kegiatan Lesson study ini, profesionalisme guru dapat ditingkatkan (Dudley, 2014; Nurwidodo, dkk., 2020; Setyawan., Permana., 2019; Mulyani, 2014) Pembinaan profesionalisme guru dilakukan dengan membentuk learning community di antara guru sehingga guru bisa saling asah, asih dan asuh di 
dalam membuat perencanaan pembelajaran, melaksanakan pembelajaran dan merefleksi pelaksanan yang telah dilaksanakan. Pola pemikiran Lesson study disesuaikan dengan perkembangan untuk menyongsong sekolah model abad 21 dan keberlanjutannya (Hosnan, 2014) Sekolah perlu mereformasi pembelajarannya dalam bentuk learning community dan colaboratif learning dengan cara ber lesson study yang lebih dikenal dengan LS-LC atau Lesson Study Learning Community (Masaaki, 2014).

Penerapan lesson study dalam pembelajaran telah banyak dilakukan orang (Wahyuni, S., Susetyorini, R. E., \& Latifa, 2015; Suratno, 2012; Hikmawati et al., 2020; Gunawan, 2018; Marina, 2016; Sumiyati, 2017; Yalcin Arslan, 2019). Penelitian sebelumnya terkait Lesson study learning Community (LS-LC) di Kota Batu Jawa Timur juga pernah dilakukan (Budiyanto et al., 2021; Susetyarini,Rofieq,Latifa, 2019). Namun demikian penelitian terkait LS-LC yang memfokuskan pada aspek kemampuan kolaboratif dan komunikatif siswa di SD N Junrejo 1 belum pernah dilakukan. Hasil observasi sebelumnya, terkait pelaksanaan pembelajaran di SD Negeri I Junrejo kota Batu adalah $90 \%$ guru cenderung menggunakan metode diskusi dalam proses pembelajaran di kelas, namun guru belum sepenuhnya mengarahkan pembelajaran kolaboratif karena di dalam metode diskusi belum terjadi saling belajar antar anggota kelompok. Kondisi perserta didik kelas 2 di SDN Junrejo 1, belum menampakkan kerjasama yang baik, dalam pembelajaran cenderung didominasi oleh salah satu orang yang aktif sehingga siswa cenderung untuk saling bersaing mendapatkan nilai yang tinggi di dalam pembelajaran. Maka perlu diimplementasikan pembelajaran kolaboratif pada kegiatan pembelajaran, berbasis LS-LC.

Pembelajaran kolaboratif meliputi dari 3 hal, yaitu 1). Pembelajaran yang sejalan dengan karateristik mata pelajaran atau pembelajaran otentik 2). Hubungan saling belajar (hubungan saling mendengarkan), 3). Terdapat lompatan/jumping (pembelajaran yang bersifat kritis, kreatif dan menantang (Sato, 2014a) Kolaborasi, yang dibedakan dari kerja sama, koordinasi, dan kegiatan kolektif, didefinisikan sebagai upaya berkelanjutan dan bersama untuk mengelaborasi "ruang masalah bersama" representasi bersama dari masalah yang akan dipecahkan (Baker, 2015) Pengajaran kolaboratif mempunyai 6 langkah utama (Joyce \& Weil, 1996) yaitu :

1. Tujuan pembelajaran dan memotivasi peserta didik tersampaikan;

2. Bahan bacaan yang diperlukan disampaikan;

3. Pembentukan kelompok diskusi;

4. Mendampingi kelompok diskusi;

5. Melakukan evaluasi pada hasil belajar kelompok dan mempresentasikan;

6. Memberikan reward pada kelompok atau individu.

Lesson Study (LS) menekan pada pembentukan komunitas belajar (learning society) yang secara keberlanjutan dan sistematis melakukan refleksi diri, pada setiap individu maupun manajerial. Kolaborasi secara berkesinambungan dalam melaksanakan plan, do, see dan melaporkan hasil proses pembelajaran (Hendayana, Suryadi, Supriatna, Imansyah, 2009; Ibrahim, 2010). Tahap perencanaan (plan), pelaksanaan ( $d o$ ) dan refleksi (see) pada LS terlaksana dengan baik bila dilakukan oleh sekelompok guru, secara berkala dan berkelanjutan (sustainability) untuk meningkatkan kompetensi dan keprofesionalan guru. Kegiatan LS dalam pembelajaran, selain sebagai upaya mengaktifkan siswa berdampak pada guru dapat melakukan review terhadap kinerja guru dan pengembangan kemampuan akademik dan berpikir kritis siswa serta menumbuhkan sikap berhati-hati dan 
bertanggung jawab dalam belajar. LS akan diobservasi dan direfleksi bersamasama oleh observer dan guru model.

Dari uraian di atas maka perlu keberlanjutan pembelajaran berbasis Lesson study forLearning community di SDN I Junrejo untuk meningkatkan kualitas pembelajaran dan pembelajaran yang memperhatikan hak belajar setiap peserta didik. LSLC akan dilakukan pada kelas II SDN Junrejo 1 dengan tujuan mendeskripsikan pelaksanaan Lesson Study Learning Community di SD Junrejo I, pada materi "waktu 24 jam".

\section{METODE}

Jenis penelitian yang digunakan adalah penelitian kualitatif dengan studi kasus tunggal, dengan pemaparan secara naturalistik. Subyek penelitian adalah peserta didik kelas II Sekolah Dasar Negeri Junrejo 1 yang berjumlah 28 orang. Ada 3 tahapan pada pelaksanaan lesson study, yaitu plan (merencanakan pembelajaran), do (melaksanakan pembelajaran) dan see (merefleksi). Rencana pelaksanaan kegiatan lesson study disajikan pada Gambar 1 berikut :

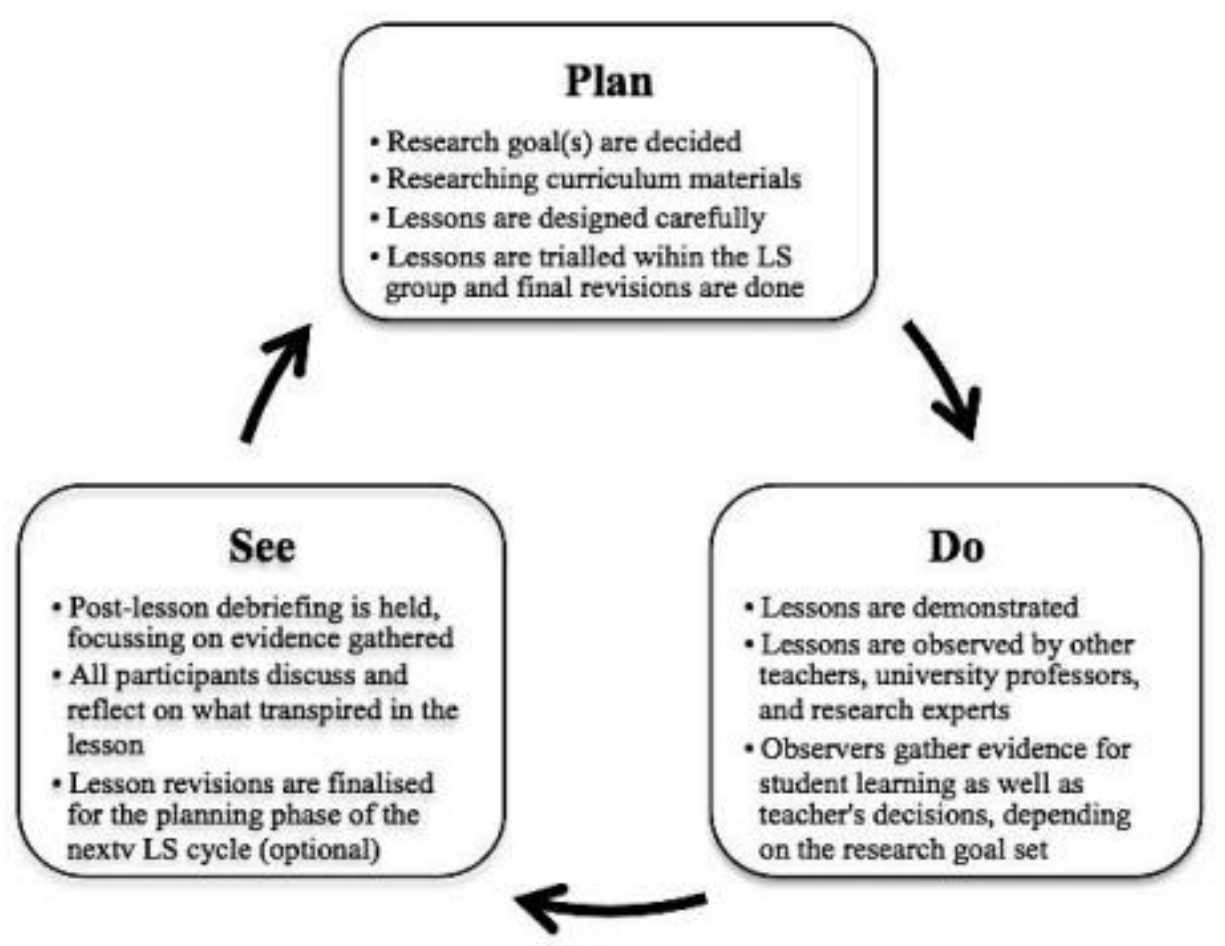

\section{Gambar 1. Rencana pelaksanaan kegiatan lesson study (diadaptasi dari Ebaeguin, M. \& Stephens, 2014, 2016)}

Pada saat plan:guru-guru merancang pembelajaran bersama-sama, menetapkan materi dan tujuan pembelajaran, membuat lesson design pada kertas manila, membuat RPP satu lembar, merancang metode pembelajaran, menyiapkan media bersama sama, guru lain dan dosen, berinovasi dan berkreasi dalam merancang chapter design/lesson design serta mempertimbangkan karakteristik peserta didik. Pada tahap plan ini juga dilakukan untuk merangcang RPP, instrument untuk mengamati peserta didik saat belajar, lembar kerja peserta didik, media pembelajaran, dan evaluasi pembelajaran: non tes dan tes.

Pada saat open class (do): guru melaksanakan pembelajaran sesuai dengan Rencana Pelaksanaan Pembelajaran (RPP) dan lesson design yang telah dirancang 
bersama-sama. Beberapa guru lain, dosen/peneliti menjadi observer. Pelaksanaan pembelajaran diharapkan sesuai dengan apa yang dirancang saat plan. Observer mengamati secara mendalam dan mengumpulkan bukti-bukti terkait proses belajar siswa

Pada saat see (refleksi): guru-guru bersama dosen merefleksi pembelajaran, dengan menganalisis "apakah semua siswa sudah mendapatkan haknya yaitu belajar dengan baik?, temuan penting apa saja yang telah diperoleh melalui pembelajaran?, apa yang harus diperbaiki dalam pembelajaran berikutnya?". Pada kegiatan refleksi ini, dicari solusi bersama terkait perbaikan tindakan dalam bentuk replainning pembelajaran, yang akan digunakan untuk pembelajaran berikutnya (Ebaeguin \& Stephens, 2016; Dudley, 2014).

Instrumen yang digunakan berupa lembar observasi kegiatan pembelajaran, lembar kerja Peserta Didik (LKPD), lembar penilaian hasil belajar (pemahaman konsep), lembar observasi kemampuan kolaboratif dan komunikasi peserta didik. Teknik pengumpulan data yang digunakan dalam penelitian ini adalah tehnik dokumentasi, wawancara tidak terstruktur dan pengamatan mendalam tentang cara belajar siswa. Dokumentasi menggunakan kamera digital dan alat perekam audio visual. Data disajikan secara naratif terkait kegiatan pembelajaran. Data hasil belajar siswa materi "waktu 24 jam, meliputi pemahaman konsep, kemampuan kolaborasi dan kemampuan komunikasi siswa. Data dianalisis secara deskriptif.

\section{HASIL DAN PEMBAHASAN Implementasi LS-LC}

Hasil implementasi LS-LC pada materi "waktu 24 jam" yang dilakukan di kelas II SD Negeri Junrejo 1, telah berjalan sesuai dengan rencana awal, melalui kegiatan plan, do, see. Peningkatan kualitas pembelajaran dipaparkan secara naturalistik dengan membandingkan pembelajaran sebelum dan setelah implementasi LS-LC. sebagaimana disajikan pada Tabel 1. Diskripsi masingmasing tahapan pembelajaran dijelaskan sebagai berikut.

Hasil observasi terhadap pembelajaran sebelum pelaksanaan LS-LC menunjukkan bahwa (1) Perencanaan pembelajaran belum sepenuhnya direncanakan secara kolaboratif oleh guru. (2) Terdapat $10 \%$ guru yang pernah merencanakaan pembelajaran berkolaborasi dengan guru lain, namun pelaksanaannya belum sesuai dengan yang diharapkan. (3)

Penyiapan logistik pembelajaran seperti media pembelajaran, pengaturan kelas, penyiapan fasilitas belum difokuskan untuk memfasilitasi penyiapan fasilitas pembelajaran abad 21 (4) Pelaksanaan pembelajaran dilakukan guru secara mandiri (5) Kegiatan pembelajaran masih sangat didominasi oleh guru, (6) Guru belum memfokuskan pada permasalahan yang terjadi pada peserta didik (7) Refleksi terhadap proses pembelajaran sudah pernah dilakukan tetapi belum paham hal-hal apa saja yang harus diungkap. Peserta didik memahami materi sebanyak 40\%, kemampuan kolaborasi siswa belum terlihat ,kemampuan komunikasi siswa belum dapat didiskripsikan. 
Tabel 1. Kegiatan pembelajaran di SDN Junrejo 1, sebelum \& setelah LS-LC

\begin{tabular}{|c|c|c|c|}
\hline No & $\begin{array}{c}\text { Kegiatan } \\
\text { Pembelajaran }\end{array}$ & $\begin{array}{c}\text { Sebelum } \\
\text { LS-LC }\end{array}$ & $\begin{array}{c}\text { Sesudah } \\
\text { LS-LC }\end{array}$ \\
\hline 1 & $\begin{array}{l}\text { Perencanaan } \\
\text { ajaran) }\end{array}$ & $\begin{array}{l}1.10 \% \text { guru yang pernah } \\
\text { merencanakaan pembelajaran } \\
\text { berkolaborasi dengan guru } \\
\text { lain } \\
\text { 2. Perencanaan pembelajaran } \\
\text { belum sepenuhnya } \\
\text { dirancang secara kolaboratif } \\
\text { 3.Penyiapan logistik } \\
\text { pembelajaran belum } \\
\text { ditekankan pada penyiapan } \\
\text { fasilitas pembelajaran abad } \\
\text { 21 }\end{array}$ & $\begin{array}{ll}\text { 1. } 20 \% \text { guru yang pernah } \\
\text { merencanakaan pembelajaran } \\
\text { berkolaborasi dengan guru lain } \\
\text { 2. Perencanaan pembelajaran } \\
\text { dirancang secara kolaboratif } \\
\text { lebih bermakna, sebagai berikut. } \\
\text {-Guru berkolaborasi dengan guru } \\
\text { lain untuk berinovasi dan } \\
\text { berkreasi dalam meranca ng } \\
\text { lesson design } \\
\text { - Guru memfokuskan pada } \\
\text { permasalahan yang terjadi pada } \\
\text { peserta didik } \\
\text { 3. Penyiapan logistik pembelajaran } \\
\text { (media, mengatur kelas,fasilitas) } \\
\text { dirancang untuk memenuhi hak } \\
\text { belajar siswa, memahami materi } \\
\text { berkomunikasi dan berkolaborasi } \\
\text { di dalam kelas }\end{array}$ \\
\hline 2 & $\begin{array}{l}D O \text { (pelaksanaan } \\
\text { Pembelajaran) }\end{array}$ & $\begin{array}{l}\text { 1. Guru melakukan } \\
\text { pembelajaran secara } \\
\text { mandiri } \\
\text { 2. Kegiatan pembelajaran } \\
\text { masih sangat didominasi } \\
\text { oleh guru, } \\
\text { 3. Guru belum memfokuskan } \\
\text { pada permasalahan yang } \\
\text { terjadi pada peserta didik }\end{array}$ & $\begin{array}{l}\text { 1. Guru model membuka kelas, } \\
\text { diobservasi oleh beberapa } \\
\text { kolega guru yang berperan } \\
\text { sebagai observer dan didampingi } \\
\text { oleh dosen } \\
\text { 2. Observer mengamati } \\
\text { pembelajaran berfokus pada } \\
\text { kemampuan pemahaman, } \\
\text { kolaboratif dan komunikasi } \\
\text { 3. Guru melaksanakan } \\
\text { pembelajaran sesuai lesson } \\
\text { design yang telah dirancang } \\
\text { bersama-sama }\end{array}$ \\
\hline 3 & $\begin{array}{l}\text { SEE ( Refleksi } \\
\text { Pembelajaran) }\end{array}$ & $\begin{array}{l}\text { Refleksi terhadap proses } \\
\text { pembelajaran sudah pernah } \\
\text { dilakukan tetapi belum paham } \\
\text { hal-hal apa saja yang harus } \\
\text { diungkap. } \\
\text { 1. Peserta didik memahami } \\
\text { materi sebanyak } 40 \% \\
\text { 2. Kemampuan kolaborasi } \\
\text { siswa belum terlihat, } \\
\text { 3. Kemampuan komunikasi } \\
\text { siswa belum dapat } \\
\text { didiskripsikan. }\end{array}$ & $\begin{array}{l}\text { Hasil refleksi didapatkan temuan } \\
\text { sebagai berikut : } \\
\text { 1.Peserta didik memahami materi } \\
\text { sebanyak } 60 \% \\
\text { 2. Peserta didik mampu berkolaborasi } \\
\text { dalam kelompok sebanyak } 3 \\
\text { kelompok (sekitar } 45 \% \text { ) } \\
\text { 3.Peserta didik berkomunikasi } \\
\text { mengungkapkan senang, gembira, } \\
\text { semangat dan ceria sebanyak } 90 \% \text {. } \\
\text { Perlu replanning dengan perubahan } \\
\text { pengaturan tempat duduk, pengaturan } \\
\text { kelompok }\end{array}$ \\
\hline
\end{tabular}




\section{Perancangan Pembelajaran}

Hasil pada saat Plan, guru berkolaborasi dengan guru lain untuk berinovasi dan berkreasi dalam merancang lesson design beserta RPP 1 lembar untuk materi waktu 24 jam dengan mempertimbangkan karakteristik peserta didik. Hasil Lesson design disajikan pada Gambar 2 dan Gambar 3.

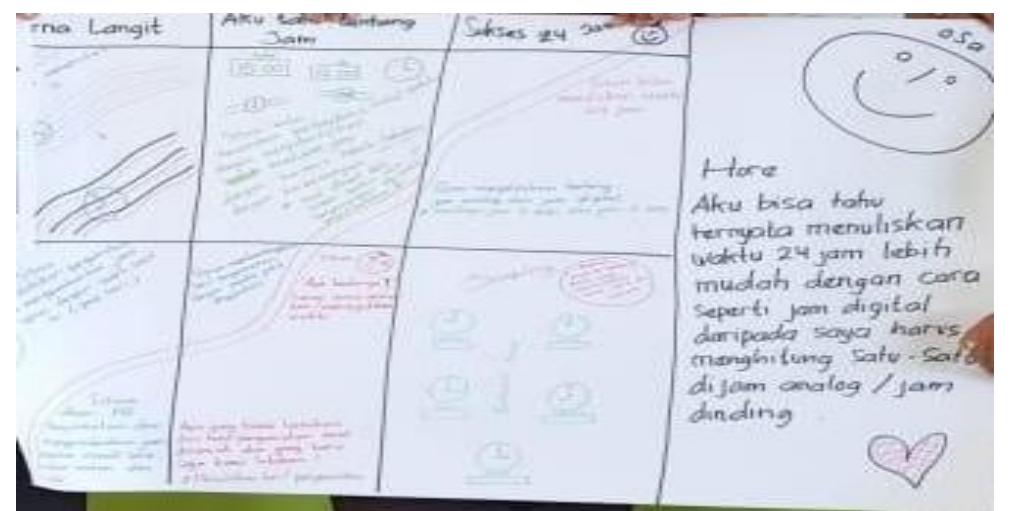

Gambar 2. Lesson Design Materi 24 Jam

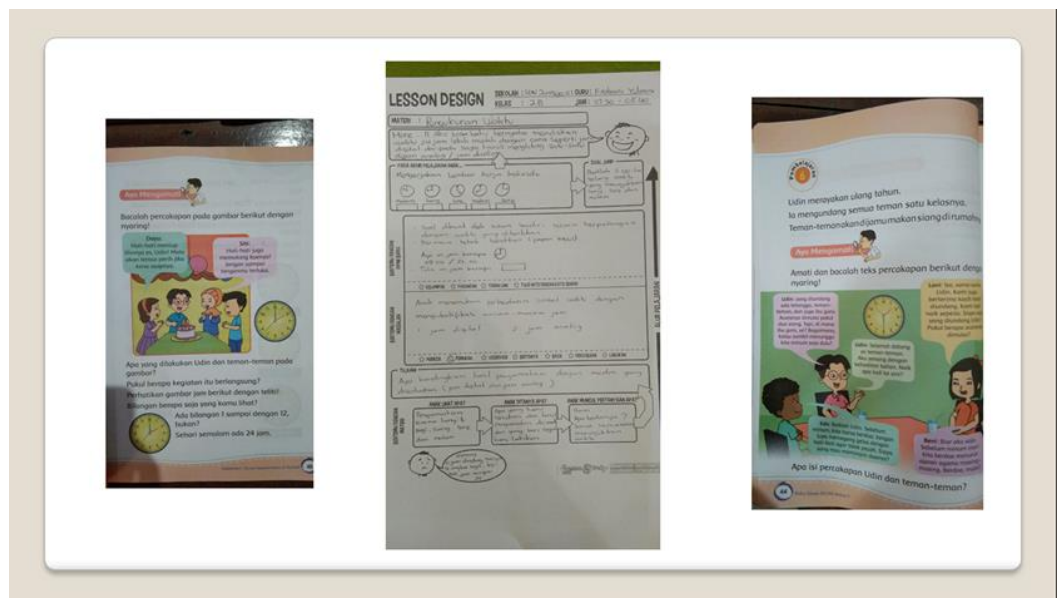

Gambar 3. Lesson design, RPP 1 Lembar dan materi

Temuan, saat merancang lesson design (plan), memfokuskan pada permasalahan yang terjadi pada peserta didik, merancang logistik pembelajaran yaitu berupa media, pengaturan kelas dan fasilitas sehingga proses berfikir, kolaborasi, dan komunikasi peserta didik dapat terbangun. Saat berkolaborasi antara guru model dengan guru dan dosen untuk membentuk komunitas belajar. Sebagaimana dinyatakan oleh (Mulyani, 2014) Agar pembelajaran dapat menjadi baik atau bermutu, maka perlu adanya komunitas belajar. Dengan adanya Komunitas belajar, dapat memfasilitasi anggotanya untuk saling belajar, saling koreksi, saling menghargai, saling bantu, saling menahan ego, saling asah, asih dan asuh dan bersifat kolegial (Hendayana, S, Suryadi, D, Supriatna, A, Imansyah, 2009; Kemmis, 2009; Mulyani, 2014; Nurwidodo, N., Hendayana, S., Hindun, I., \& Sarimanah,E., 2018), pendapat tersebut sesuai dengan harapan menteri pendidikan, guru abad 21 merupakan guru penggerak reflektif. Guru menjadi pembelajar sepanjang karir, bekerja sama, saling belajar dan berdiskusi dengan kolega 
(Susetyarini, E; Rofieq, A.N, Latifa, 2019). Pembelajaran berbasis Lesson study akan meningkatkan kualitas pembelajaran. Lesson study melatih guru secara keberlanjutan untuk merancang pembelajaran secara terstruktur, meningkatkan kreativitas dan inovasi, sehingga profesionalisme guru meningkat lebih baik (Muntaqo, R., Masruroh, 2016; Rizki, 2014). Guru akan terbiasa menggunakan pembelajaran kolaboratif berbasis Lesson Study Learning Community (LSLC) saat open class sehingga pembelajaran lebih menarik akan berakibat pada peningkatan hasil belajar atau capaian akademik siswa (Hastin Atas \& Hobri., Ervin, Oktavianingtyas., 2018).

Rencana pembelajaran (lesson design) dan peta konsep (chapter design) pembelajaran kolaboratif pada "materi waktu 24 jam" telah tersusun. Tahap selanjutnya guru model melakukan pembelajaran di kelas, diobservasi oleh beberapa guru lain yang bertindak sebagai observer dan dipanatu oleh dosen. Saat pelaksanaan pembelajaran focus yang diamati pada pembelajaran kolaboratif dan kemampuan komunikasi untuk mengungkapkan perasaan masing masing setelah mengikuti pembelajaran, dan hasil belajar peserta didik.

\section{Pelaksanaan Pembelajaran}

Pada saat open class (pelaksanaan pembelajaran): guru melaksanakan pembelajaran sesuai dengan RPP dan lesson design yang telah dirancang bersamasama. Langkah pembelajaran yang pertama: Peserta didik mengamati langit di luar kelas tentang melihat warna langit, selanjutnya, peserta didik kembali ke kelas untuk berdiskusi yang dibimbing oleh guru model, kemudian guru model mengarahkan hasil pengamatan peserta didik dengan materi, yaitu membandingkan antara jam digital dan non digital. Observer mengamati peserta didik tentang apa yang dipelajari.

Pembelajaran diawali dengan persiapan kelas, salam, doa bersama, dan presensi kelas. Apersepsi dilakukan guru melalui tanya jawab tentang penugasan sebelumnya terkait pengamatan warna langit pada waktu malam hari. Pada kegiatan inti, peserta didik diajak secara bersama sama ke luar kelas untuk mengamati warna langit, di pagi hari, setelah sebelumnya dilakukan pembagian kelompok. Dari 28 siswa, dibagi menjadi 7 kelompok, dengan jumlah anggota perkelompok 4 orang. Setelah selesai kegiatan observasi di luar kelas, siswa berdisikusi kelompok dan berkolaborasi untuk membuat laporan terkait penemuan hasil observasi, kemudian membandingkannya dengan waktu melalui jam digital dan jam manual. Peserta didik berdiskusi secara kelompok dan berkolaborasi untuk menyelesaikan Lembar Kerja Peserta Didik (LKPD) yang telah diberikan oleh guru, terkait dengan pembacaan jam digital, pembacaan jam manual. Perwakilan masing-masing kelompok siswa, maju ke depan kelas untuk mempresentasikan temuannya. Selanjutnya guru memberikan penguatan dengan penjelasan lisan maupun dengan menulis di papan tulis, selain itu guru juga memutar video untuk memberikan penguatan terkait waktu dan jam.

Pada akhir pembelajaran siswa mengerjakan soal evaluasi secara individu untuk menuliskan jam baik secara digital dan manual. Selanjutnya setiap siswa diberi kesempatan untuk mengungkapkan perasaannya setelah belajar tentang waktu 24 jam dan melihat langit. Siswa diminta menuliskan telah belajar apa pada hari itu dan tentang hal hal yang disukai dari pembelajaran tersebut. Pembelajaran ditutup dengan doa, tindak lanjut untuk materi berikutnya, serta ungkapan rasa 
syukur kepada Sang Pencipta. Kegiatan peserta didik saat open class disajikan pada Gambar 4.

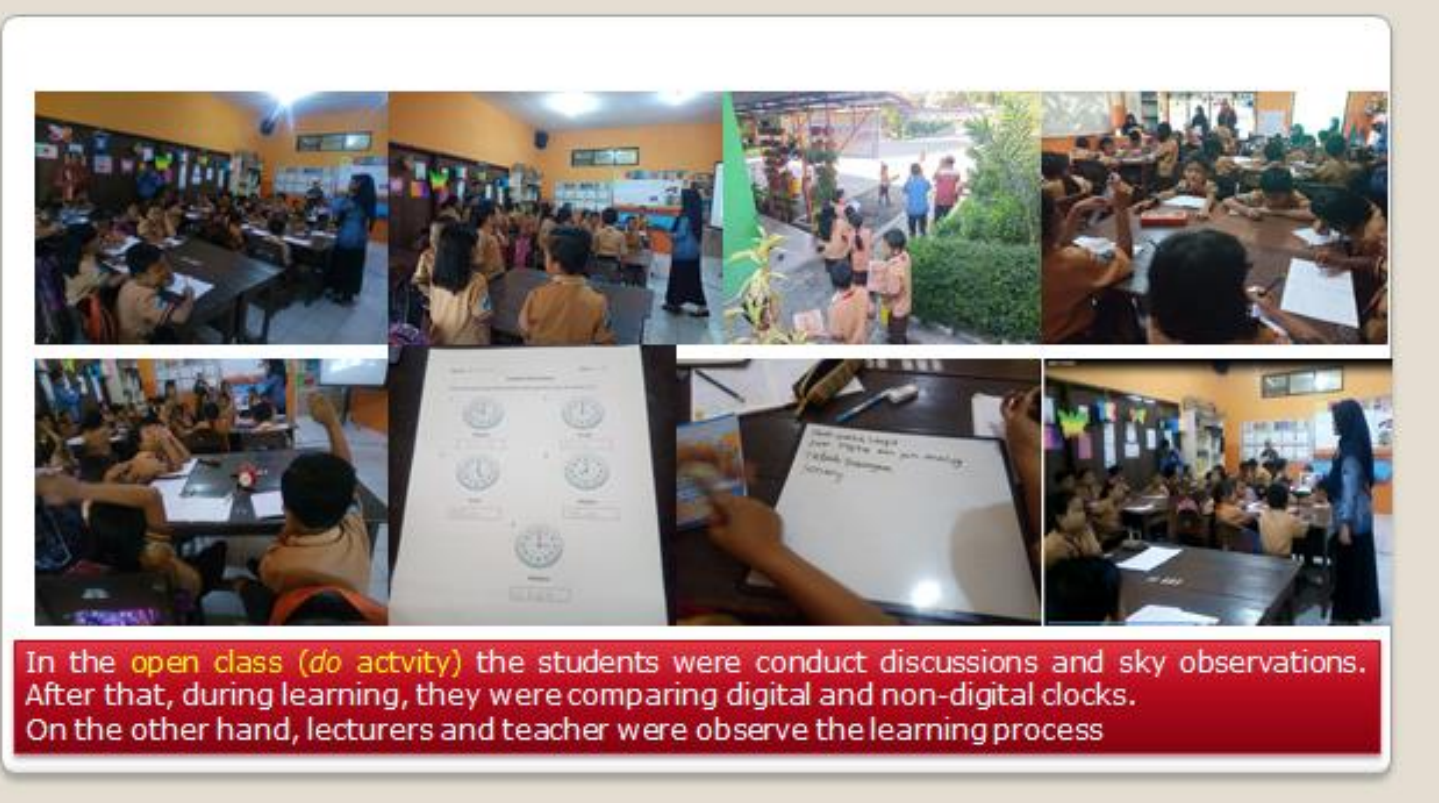

Gambar 4. Kegiatan open class SDN I Junsa 2019

Temuan saat open class peserta didik berdiskusi antar teman untuk memecahkan permasalahan yang diberikan oleh guru model, peserta didik berkolaborasi, berkomunikasi dengan temannya dalam kelompok. Hal ini sesuai sejalan dengan pendapat (Susetyarini, E; Rofieq, A.N, Latifa, 2019), yang menyatakan bahwa pada pelaksanan pembelajaran, fokus pada peserta didik, melakukan, kolaboratif, komunikasi dan berkreasi. Pembelajaran kolaboratif sesuai teori Vygotsky (Naldi, H 2018) dan teori komunikasi oleh Dewey. (Zulkarnain, 2020). Saat berdiskusi antar peseta didik mempunyai makna 'saling belajar'. Lesson study learning community menekankan peserta didik untuk saling belajar (peserta didik A mendengarkan pendapat peserta didik B atau sebaliknya), pembelajaran yang memperhatikan karakteristik peserta didik dan materi yang akan disampaikan sesuai dengan kurikulum yang berlaku, serta ada soal jumping task (Hots), yaitu pembelajaran yang bersifat, kritis, kreatif dan menantang (Hendra Naldi, 2018; Sato, 2014; Mulyani, 2014).

\section{Refleksi Pembelajaran}

Pada saat refleksi (see): observer dari guru dan dosen mengungkapkan tentang peserta didik saat diskusi dan hasil belajar tentang materi waktu 24 jam (Gambar 5). Hasil refleksi didapatkan temuan sebagai berikut :

1. Peserta didik memahami materi sebanyak $60 \%$

2. Peserta didik mampu berkolaborasi dalam kelompok sebanyak 3 kelompok (sekitar 45\%)

3. Peserta didik berkomunikasi mengungkapkan senang, gembira, semangat dan ceria sebanyak $90 \%$.

4. Perlu replanning dengan perubahan pengaturan tempat duduk, pengaturan kelompok dan anggota kelompok 


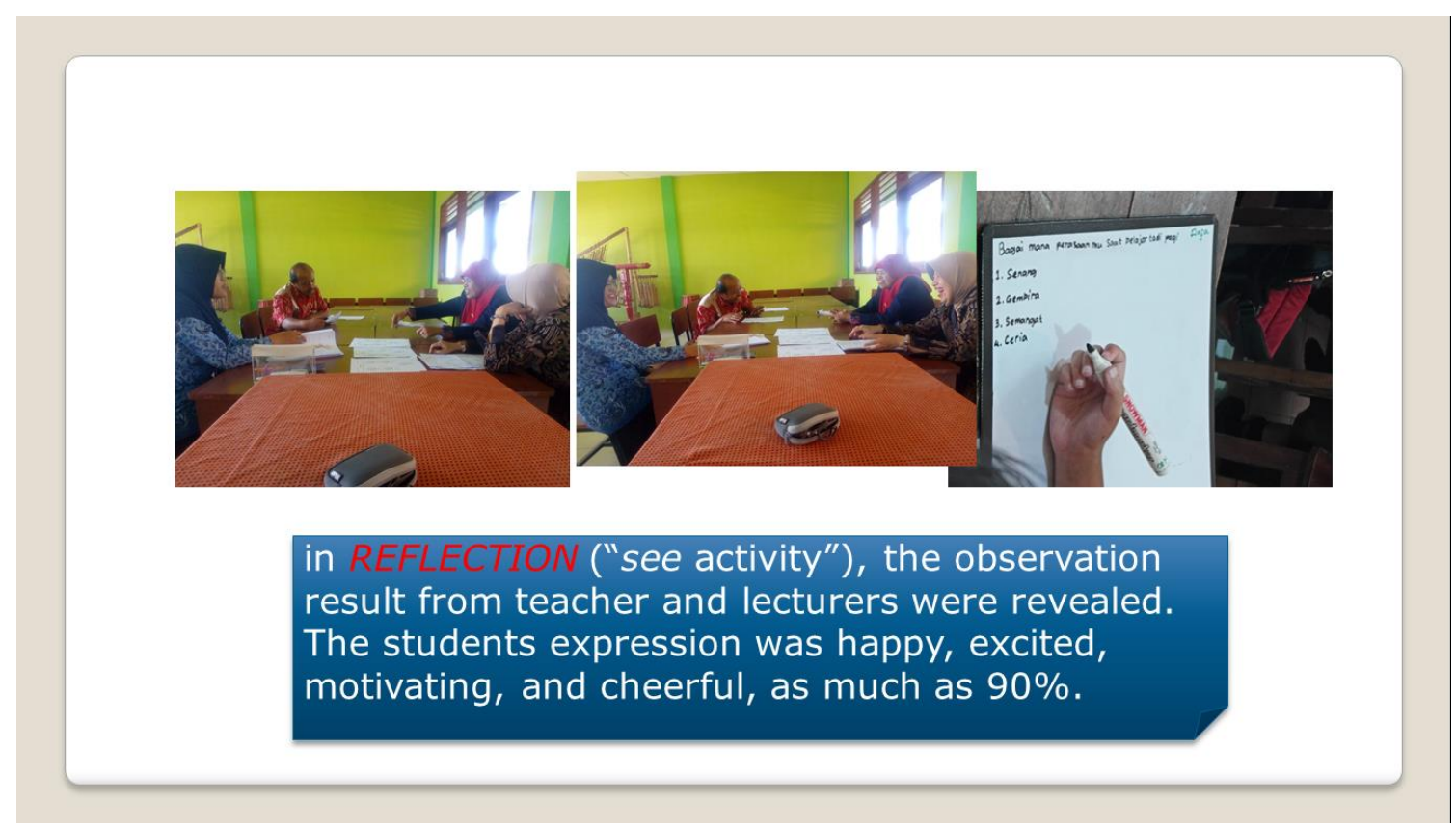

Gambar 5. Kegiatan refleksi SDN I Junsa 2019

Menurut Wardani, dkk (2012) hasil belajar merupakan keseluruhan hasil pengukuran kognitif, dan aspek perilaku baik melalui tes maupun non tes yang dilakukan pada akhir pembelajaran. Ketercapaian hasil belajar dapat diketahui dengan melakukan pengukuran tersebut. Selain itu diperkuat pendapat Purwanto, (2013) bahwa hasil belajar merupakan perubahan perilaku peserta didik yang terjadi setelah mengikuti proses belajar mengajar sesuai dengan tujuan pendidikan. Perubahan tersebut dikarenakan peserta didik telah mencapai penguasaan atas sejumlah bahan yang diberikan selama proses pembelajaran. Lebih lanjut lagi Purwanto menyatakan bahwa ranah hasil belajar meliputi pemahaman konsep yang termasuk aspek kogintif, keterampilan proses atau aspek psikomotorik dan sikap siswa aspek afektif. Pernyataan tersebut didukung dari hasil penelitian, bahwa hasil belajar peserta didik dapat ditingkatkan melalui lesson study (Sucilestari, Arizona, 2019). Konsep pelaksanaan Lesson study peserta didik belajar untuk berkolaborasi, dimana peserta didik saling belajar dan bekerja sama dalam kelompok kecil untuk meningkatkan pencapaian hasil belajar dalam proses belajar (Dewi et al., 2016) Selain kolaborasi peserta didik juga berkomunikasi dengan temannya dengan perasaan yang senang, hal ini didukung oleh (Suhaedi \& Harahap, 2018) komunikasi merupakan suatu kemampuan yang harus dimiliki oleh peserta didik dalam mempelajari materi-materi matematika. Penguasaan akan kemampuan ini bisa dicapai melalui partisipasi aktif siswa secara kolaboratif selama proses pembelajaran dilakukan. Lesson Study menjadi bagian pembelajaran yang dapat menumbuhkembangkan kemampuan komunikasi matematis peserta didik. Pada open class memberikan ruang yang cukup bagi peserta didik untuk mengkontruksi kemampuan komunikasi melalui diskusi kelompok dan diskusi kelas. Pembinaan profesionalisme guru salah satunya melalui Lesson study, hal ini dikarenakan saat plan (perencanaan pembelajaran) terbentuk komunitas belajar secara kolaboratif yang saling asah, asih, asuh berdasarkan prinsip prinsip kolegalitas dan mutual learning, saat do (pelaksanaan 
pembelajaran) serta saat see (refleksi) untuk membicarakan temuan dan kebelanjutan pembelajaran (Zubaidah, 2010). Dengan demikianLesson study sebagai bentuk CPD (Continuing Professional Development), mengutamakan kebelanjutan (Continues Improvement), untuk replanning pembelajaran selanjutnya dengan memperhatikan saran dari observer. Sesuai pendapat (Hikmawati et al ., 2020) Kualitas pembelajaran dapat ditingkatkan melalui Lesson study, berdampak pada peningkatan profesionalisme guru.

\section{SIMPULAN}

Pelaksanaan Lesson Study Learning Community dikelas II SD Junrejo I, pada materi "waktu 24 jam" telah berjalan dengan baik. Peserta didik mampu memahami materi sebanyak 60\%, mampu berkolaborasi dalam kelompok sebanyak 45\%, mampu mengungkapkan perasaan senang, gembira, semangat dan ceria sebanyak 90\%. Terdapat peningkatan kemampuan pemahaman kolaborasi dan komunikasi pada peserta didik. Perlu replanning dengan perubahan pengaturan tempat duduk, pengaturan kelompok dan anggota kelompok.

Saran yang diberikan, guru hendaknya berkomitmen untuk mendesain pembelajaran Lesson Study Learning Community agar kemampuan berdiskusi dan kolaborasi dan hasil belajar siswa kelas II SD dapat meningkat. Program LSLC di SDN Junrejo I perlu dilanjutkan dan ditingkatkan.

\section{DAFTAR PUSTAKA}

Alshwaikh, J., \& Adler, J. (2017). Researchers and teachers as learners in Lesson Study. March.

Anwar, M. (2017). Menciptakan Pembelajaran Efektif Melalui Hypnoteaching. Ekspose, 16, 469-480. https://doi.org/https://doi.org/10.30863/ekspose. v16i2.106

Asanuma, S. (2012). Lesson study and curriculum politics in contemporary Japan. Asia Pacific Journal of Educational Development, 1(1), 25-32. https://doi.org/10.6228/APJED.01.01.03

Baker, M. J. (2015). Collaboration in Collaborative Learning. Interaction Studies: Social Behaviour and Communication in Biological and Artificial Systems, 16(3), 94-114.

Budiyanto, A. K., Rahardjanto, A., \& Hadi, S. (2021). Sustainability of Lesson Study on The Lesson Study for Learning Community ( LSLC) Program in Batu City East Java Province. 5(1), 41-49.

Christ, T., Arya, P., \& Chiu, M. M. (2017). Relations among resources in professional learning communities and learning outcomes. Teaching Education, 28(1), 94-114. https://doi.org/10.1080/10476210.2016.1212826

Coenders, F, \& Verhoef, N. (2018). Lesson study: professional development (PD) for beginning and experienced teachers. Professional Development in Education, 45(2), 217-230. https://doi.org/https://doi.org/10.1080/19415257. 2018.1430050

Dewi, M. R., Mudakir, I., \& Murdiyah, S. (2016). Pengaruh Model Pembelajaran Kolaboratif Berbasis Lesson Study terhadap Kemampuan Berpikir Kritis Siswa. The Effect of Collaborative Learning Model with Lesson Study on Student Critical Thingking. Jurnal Edukasi Unej, III(2), 29-33.

Dudley, P. (2014). Lesson study a handbook. http://lessonstudy.co.uk/wp- 
content/uploads/2012/03/new-handbook-revisedMay14.pdf

Ebaeguin, M. \& Stephens, M. (2014). Cultural challenges in adapting lesson study to a Philippines setting. Mathematics Teacher Education and Development, 16(1), 43-64.

Ebaeguin, M. \& Stephens, M. (2016). Key Elements of a Good Mathematics Lesson as Seen by Japanese Junior High School Teachers. In White, B., Chinnappan, M. \& Trenholm, S. (Eds.). Opening up Mathematics Education Research (Proceedings of the 39th Annual Conference of the Mathematics Education Research Group of Australasia), 206-213.

Gunawan, I. (2018). The Implementation of Lesson Study Based Learning Management and the Effect toward Students' Activeness in Lecturing. JPP (Jurnal Pendidikan Dan Pembelajaran), 24(2), 51-63. https://doi.org/10. 17977/um047v24i22017p051

Hastin Atas, A., \& Hobri., Ervin, Oktavianingtyas. (2018). Pengaruh Pembelajaran Kolaboratif Berbasis Lesoon Study Learning Community (LSLC) terhadap Hasil Belajar pada Pokok Bahasan Peluang. Kadikma, 9(3), 183-193. https://doi.org/https://doi.org/10.19184/kdma.v9i3.11552

Hendayana, S, Suryadi, D, Supriatna, A, Imansyah, H. (2009). Lesson Study: Pengembangan Profesi Guru. Rizqi Press.

Hikmawati, Agus Ramdani, Gito Hadiprayitno, Muntari, M. H. (2020). Jurnal Pengabdian Masyarakat Sains Indonesia (JPMSI). Jurnal Pengabdian Masyarakat Sains Indonesia (JPMSI), 2(2), 108-112. https://doi.org/ 10.29303/jpmsi.v2i2.44

Hikmawati, H., Ramdani, A., Hadiprayitno, G., Muntari, M., \& Haris, M. (2020). Pendampingan Peningkatan Mutu Pembelajaran IPA Melalui Lesson Study for Learning Community (Lslc) Di Smp Kota Mataram. Prosiding Konferensi Nasional Pengabdian Kepada Masyarakat Dan Corporate Social Responsibility (PKM-CSR), 3, 777-783. https://doi.org/10.37695/pkmcsr. v3i0.826

Hosnan. (2014). Pendekatan Scientific dan Kontekstual dalam Pembelajaran Abad 21. Ghalia Indonesia.

Ibrahim, S. (2010). Pembelajaran Lesson Study. UM Press.

Joyce, B. \& W. M. (1996). Models of Teaching. Allyn and Bacon.

Kemmis, S. (2009). Understanding professional practice: A synoptic framework In B. Green (Ed.), Understanding and researching professional practice. Sense Publisher.

Kurniawan, R. Y. (2016). Identifikasi permasalahan pendidikan di Indonesia untuk meningkatkan mutu dan profesionalisme guru. Konvensi Nasional Pendidikan Indonesia, 1415-1420.

Marina, C. (2016). Peningkatan Pemahaman Konsep dan Hasil Belajar Materi Penyesuaian Makhluk Hidup Dalam Pembelajaran Kooperatif Tipe ThinkPair-Share Dipadu dengan Model Picture and Picture yang Dikembangkan Melalui Lesson Study. JINoP (Jurnal Inovasi Pembelajaran), 2(1), 256. https://doi.org/10.22219/jinop.v2i1.3284

Masaaki, S. (2014). Dialog dan Kolaborasi di Sekolah Menengah Pertama Praktek Learning Community. Pelita.JICA.

Mulyani, S. (2014). Meningkatkan Profesionalitas Pendidik Melalui Lesson Study. DEIKSIS, 06, 115-122. http://jurnal.ugj.ac.id/index.php/Deiksis/issue/archive

Muntaqo, R., Masruroh, D. (2016). Lesson Study dalam Peningkatan Kualitas 
Pembelajaran di Madrasah Ibtidaiyah Ma'arif Kejiwan Wonosobo. BELAJEA : Jurnal Pendidikan Islam, 1, 125-144. https://doi.org/10.29240/ bjpi.v1i2.107

Naldi, H. (2018). Perkembangan Kognitif, Bahasa, Dan Perkembangan Sosioemosional serta Implikasinya dalam Pembelajaran. Jurnal Socius: Journal of Sociology Research and Education, 15(2), 102-114. https://doi.org/: https://doi.org/10.24036/scs.v5i2.110

Nurwidodo, N., Hendayana, S., Hindun, I., \& Sarimanah,E. (2018). Strategies for establishing networking withpartner schools for implementing lesson study in Indonesia. Jurnal Pendidikan Biologi Indonesia, 4(1), 11-22. https://doi.org/https://doi.org/10.22219/ jpbi.v4i1.5489

Nurwidodo, Sri Wahyuni, D. (2020). Panduan PLP 1.

Peraturan Pemerintah RI. (2013). Peraturan Pemerintah Republik Indonesia Nomor 32 Tahun 2013 Tentang Standar Nasional Pendidikan. In Sekretariat Negara (Vol. 2).

Purwanto. (2013). Evaluasi Hasil Belajar. Pustaka Pelajar.

Ramdhani Sucilestari dan Kurniawan Arizona. (2019). Transformasi. Jurnal Pengabdian Masyarakat, 15(1), 23-34.

Rizki, S. (2014). Efek Lesson Study Terhadap Peningkatan Kompetensi Pedagogik Calon Guru. AKSIOMA, Jurnal Pendidikan Matematika FKIP Univ. Muhammadiyah Metro, 3, 17-27. https://doi.org/: 10.24127/ajpm.v3i1.377

Rock, T. C., \& Wilson, C. (2005). Improving teaching through lesson study. Teacher Education Quarterly, 32(1), 77-92.

Sato. (2014a). Dialog Kolaboratif di Sekolah Menengah Pertama Praktek "Learning Community. JICA (Japan International Cooperation Agency).

Sato. (2014b). Mereformasi Sekolah. Konsep dan Praktek Komunitas Belajar. Pelita. JICA.

Setyawan,D., PermanaT.I., L. . (2019). Lesson study for learning community: A way of collegial participation of teachers and lecturers. JURNAL BIOEDUKATIKA, 7, 1-10. https://doi.org/10.26555/bioedukatika.v7i1.11936

Suhaedi, D., \& Harahap, E. (2018). Membangun Kemampuan Komunikasi Matematis Siswa Melalui Lesson Study: Sebuah Perspektif. Matematika, 17(1), 41-45. https://doi.org/10.29313/jmtm.v17i1.4564

Sumiyati, E. (2017). Penggunaan Model Pembelajaran Interaktif Berbasis Aktivitas Untuk Meningkatkan Prestasi Belajar Siswa Kelas Vi Pada Pelajaran Pkn Sd Negeri 09 Kabawetan. Jurnal PGSD, 10(2), 66-72. https://doi.org/10.33369/ pgsd.10.2.66-72

Suratno, T. (2012). Lesson Study as Practice: An Indonesian Elementary School Experience. Online Submission, 7, 627-638.

Susetyarini, E; Rofieq, A.N, Latifa, R. (2019). Implementasi Lesson study for Learning community Guru-Guru SMPM 8 Kota Batu Laporan PPMI DPPM $U M M$.

Susetyarini, Eko; Rofieq, Ainur;Latifa, R. C. S. W. (2019). Lesson Study for Learning Community in teaching Human Body Skeleton Material In Muhammadiyah 8 Yunior High School Batu. 6th International Conference on Community Development (ICCD 2019), 472-475. https://creativecommons. org/licenses/by-nc/4.0/

Susetyarini, R. E., Wahyuni, S., \& Latifa, R. (2015). Kemampuan berpikir kritis mahasiswa pada matakuliah embriologi dan reproduksi hewan melalui lesson 
study. Prosiding Seminar Nasional Pendidikan Biologi, 774-781. https://researchreport.umm.ac.id/index.php/resear chreport/article/view/520/744

Wahyuni, S., Susetyorini, R. E., \& Latifa, R. (2015). Peningkatan kemampuan berpikir kritis mahasiswa pendidikan biologi UMM melalui lesson study. JINoP (Jurnal Inovasi Pembelajaran), 1(2), 187-200. https://doi.org/ 10.22219/jinop.v1i 2.2571

Wahyuningtyas N, Ratnawati N, A. R. . (2015). Membangun Kolegialitas Calon Guru IPS Melalui Lesson Study. Sejarah Dan Budaya, 9, 217-222.

Wardani, N. S. (2012). AsesmenPembelajarn SD.Salatiga. Widya Sari Press.

Yalcin Arslan, F. (2019). The role of lesson study in teacher learning and professional development of EFL teachers in Turkey: A case study. TESOL Journal, 10(2). https://doi.org/10.1002/tesj.409

Zubaidah, S. (2010). Peningkatan Profesionalisme Guru melalui Kegiatan Lesson Study.

Zulkarnain, H. (2020). Ekliptis Teori Komunikasi, Sekolah Pascasarjana Doktor Ilmu Komunikasi Universitas Hasanuddin. https://doi.org/10.6084/m9. figshare. 11535483 